http://dx.doi.org/10.4314/ejotmas.v7i1-2.6

\title{
BALANCING GENDER STEREOTYPES IN NOLLYWOOD: A CONSIDERATION OF GENEVIEVE NNAJI'S LIONHEART
}

\author{
*Roselyn Vona DOGHUDJE
}

\begin{abstract}
The current increase in the protest for women's right all over the world, amidst the resurgence of feminist critical thinking in mainstream culture, is giving film researchers a lot to reflect on. Based on previous researches, it can be deduced that very little progress has been made to correct the stereotypical portrayal of women in Nollywood films by both male and female producers. In order to examine the stereotypes and investigate the extent to these stereotypes reflect the social reality of both genders in real life, Lionheart, a movie produced by a veteran Nollywood actress, Genevieve Nnaji, with an average rating of 5.6/10 on IMDB (Internet Movie Database) and was nominated for an Oscar award was selected. Quantitative content analysis was applied and findings revealed that there was an effort by the producer to 'demystify' the power of men. The issues raised in the movie are topical and relevant to the feminist discourse on women's representation in film and in the media generally. The movie also provides a way forward for gender-based discourse and serves as a point of reference for other female directors willing to interpret the role of women in a manner that is more accurate and truthfully reflective of their strengths and capacities. The study is anchored on stereotype content model (SCM).
\end{abstract}

Keywords: Gender stereotypes, Nollywood films, Lionheart, Feminist critical thinking, SCM

\section{Introduction}

The discourse about gender stereotype is on the rise and there is no sign of slowing. Every day, different researchers come up with different perspectives to understand this phenomenon. Those at the vanguard of the media and other cultural institutions are primarily at the receiving end of this tidal wave due to the nature of their responsibility as the

*Roselyn Vona DOGHUDJE is of the Department of Communication and Language Arts, Faculty of Arts, University of Ibadan, Ibadan, Nigeria

Email: frukama21@yahoo.com 
mirror of the society in which they exist and operate. The media, as a powerful institution of social orientation and transformation, is plagued by issues of gender biases especially against women. More so, it has been determined that mass media representation of the female gender shapes how the society perceives women and influences their behaviours toward them (Arpita Sharma, 2012 cited in Kumari \& Joshi, 2015).

Film, as a "powerful medium that conveys the values and beliefs of contemporary societies" according to Cloete (2017, p. 2), has become a subject of intense scrutiny for its roles in reinforcing and perpetuating gender-based stereotypes. Adewoye, Odesanya, Abubakar and Olatunji (2014) citing Okunna (2000; 1996) reveal that Nigerian films often represent women as wayward and of low moral standards, materialistic, lazy, subservient to and dependent on men and fit for domestic rather than professional careers and roles. These stereotypes have found expression in social reality as females are viewed for their domestic and vain attributes and confined to these limits. This development has formed the basis of social discourse on gender equality and is informing the actions of feminists today who are constantly pushing for a drastic change in the existing narrative. It is on this premise that this study seeks to investigate the current development in Nollywood films as regards gender stereotyping and analyse the result for any progress towards addressing this issue with a focus on the film, Lionheart.

In the constantly shifting [and progressing] landscape of gender discourse, it can be averred that little progress has been made in the manner of representation of women in Nollywood films. Okunna (2002) quoted in Adewoye, Odesanya, Abubakar and Olatunji (2014) stated that women are still represented in such negative light as materialistic, emotionally needy and problematic in the family, among other negative depictions, in Nigerian films. More so, the film, Lionheart was scripted and directed by a woman, Genevieve Nnaji. This makes it an attractive subject of investigation to discover if the patterns of gender stereotype is similar from the frame of a woman to that of men that still dominate the Nollywood film industry. Therefore, this paper seeks to, among others, interrogate the development currently unravelling in the Nigerian film industry by reviewing one of its latest releases.

The aim of this paper is to examine how Nollywood is balancing gender stereotypes of women in its movies by reviewing Lionheart. The specific objectives include to:

a. examine how both genders are stereotyped in Lionheart; and

b. investigate the extent to which these stereotypes in Lionheart reflect social perception of both genders in real life. 


\section{Research Questions}

i. How are the male and female gender stereotyped in Lionheart?

ii. To what extent do these stereotypes fit into the larger society perception of both genders?

The finding of this study will effectively highlight the state of gender-based stereotypes in Nollywood films and how it was addressed in Lionheart. Additionally, the paper will be of particular interest to researchers working on the role of gender specific stereotypes in informing gender-based perceptions and behaviours in the society.

\section{Nollywood: An Overwiew}

The Nigerian film industry is called Nollywood. Unlike its Hollywood counterpart which is obviously a place in California, Onuzulike (2009) contends that the root of the word is, apparently, derived from an imitation of Hollywood. Every film produced in Nigeria is marketed and viewed as a Nollywood product. Film researchers in Nigeria (Onuzulike, 2009; Enna, Idakwo, and Akpovye, 2015; Fosudo, 2012; Chowdhury, Landesz, Santini, Tejada and Visconti, 2008) generally agree that Ken Nnebue's 1992 blockbuster, Living in Bondage, birthed Nollywood and heralded the era of producing films in VHS, CD, and DVD in Nigeria. The extraordinary success of Living in Bondage and the awareness it created about the capacity of the local industry to produce and market motion pictures using new and cheaper audio-visual technologies laid the structure for the eventual growth of the nascent film industry we see. Today, Nollywood has positioned itself as the largest film industry in Africa and the second in the world, besides Bollywood and Hollywood, in terms of the films produced annually (Omoera, 2017).

As Onuzulike (2009) correctly observes that Nollywood films are enormously popular in Nigeria and by that, exert a huge influence on popular opinion and impact the people's culture. The rave achievements of Nollywood in respect to addressing social morality and content output have not addressed salient issues relating to quality, gender bias, and the manner in which social ills are portrayed. This view is corroborated by Opeyemi (2008, p.286) citing Musa's (2006) reports that Nollywood films "carry boring storylines, portraying low intellectualism and technical unprofessionalism." Furthermore, Opeyemi (2008) emphasizes that Nollywood films are rife with violence, rituals, poor portrayal of women and a general hint at a debased, money-obsessed Nigerian society. 


\section{Gender Representation in Nollywood}

The bulk of available research on gender representation in the Nigerian film industry centres on the portrayal of women in films. This is understandable because the authentic picture of gender representation in Nigerian films becomes clearer only when we analyze the roles assigned to women against the dominance of men. Women make roughly half of the total population of Nigeria (National Bureau of Statistics Report on Women and Men in Nigeria, 2015). They, nonetheless, appear less often than men in Nollywood films. This apparent disparity in representation and marginalization of women in Nollywood films can be ascribed to the socio-cultural roles ascribed to women in the society (Aromona, 2016).

Women, by social construction, are subject to the male gender. Films, being the mirror of society, reflect this social order in the manner in which both genders are accorded prominence and roles in films. Men generally enjoy more media exposure than women and, according to Doyle in Wood (1994 pp. 32), are shown to be aggressive, dominant, and engaged in exciting activities from which they receive rewards for. Additionally, men are seldom shown to engage in domestic chores such as cooking, cleaning or taking care of children. Films, therefore, consolidate the dominant image of men by portraying them to be competent, powerful, emotionally in control and sexually expressive (Wood, 1994). The same is true for Nollywood. The Nigerian film industry has, for a long time, been indicted for promoting the subjugation and stereotype of women in the Nigerian society. And as far as the representation of women is concerned in Nigerian films, Okunna (2005) claims that it is "business as usual."

\section{Gender Stereotype and Stereotyped Portrayal of Women in Nollywood}

The United Nation Office of the High Commissioner for Human Right (OHCHR) describes gender stereotype as a generalized view or preconception about attributes or characteristics that are or ought to be possessed by women and men or the roles that are or should be performed by men and women (OHCHR, 2014). At the core of gender stereotype is the belief that women are not and ought not to be equal to men. Ellemers (2018) points out that in gender stereotype, men are generally thought to be competent and bold while women are considered weak and emotionally functional. This perception is carried over to every aspect of life resulting in the greater marginalization of women thereby limiting their chances of advancement in society. For example, in education, men are held to be more gifted in sciences and engineering than women, and in professional life, women are 
condemned to such careers like teaching, nursing, and care giving (Ellemers, 2018).

Gender stereotype has been highlighted to be one of the causal factors of social inequalities. Furthermore, Okunna (2005) explains that the male sex appears to be the most sought after in Africa and right from birth, female children are groomed to see themselves as subordinate to their male counterparts. The fallout from this is the social, political, educational, and cultural poverty women suffer. The Council of Europe (2018) emphasizes that gender stereotype is used to "justify and maintain historical relations of power of men over women as well as sexist attitudes which are holding back the advancement of women." The active connivance of some elements of the social superstructure, of which the media institution is a primary culprit, can be argued to ensure the continued marginalization of women by men. The media, being a powerful instrument of social orientation plays to the dominant paradigm of gender stereotype by portraying women in the manner that reinforces their marginalization. Films as reflections of social conditions are even more influential. Dutt (2014, p. 4) explains that "many cultural constructions, societal norms, fantasies and historical moments are conveyed and understood through films". Therefore, it is critical that the manner in which women are represented in films is understood as it influences how they are viewed in reality.

Okafor (2017, p. 278) states that women, "through the eye of the camera, have been projected in such a manner as criminal to their person and character. The portrayal of women in Nollywood has been a subject of numerous scholarly investigations. Women characters in Nollywood films, according to Oak Foundation (2015, p. 4 ), are depicted in ways that they are 'either made appendages to men, an object of sexual gratification or lust." Adewoye, Odesanya, Abubakar, and Olatunji (2014) submit that the pattern of portraying women in Nollywood films is as sex objects, as the weaker sex, and as domestic servants. This submission is in line with the position of Ibbi (2017, p.62), who states that women in Nollywood films are stereotyped in numerous ways some of which include: femme fatal; gold diggers and trophy wife; house; an object of barter; an object of ritual and object of sexploitation. Okafor (2017) adds that the aforementioned listings feed societal perception and discriminations against women.

\section{Synopsis of Lionheart}

Lionheart follows the struggles of Adaeze (Genevieve Nnaji) to revive the failing transport and logistics business of her father, Chief Earnest Obiagu (Pete Edochie). Chief Earnest Obiagu suffers a life-threatening heart attack during a meeting with government officials, where he is to 
secure a contract that would enable them to expand their business. This necessitated his withdrawal from active managerial duties. Adaeze, who had figured that she would replace her ailing father, was shocked to learn that her father had passed her over for her uncle, Godswill (Nkem Owoh). The decision generated brewing friction between Adaeze and her clownish uncle. Being a family business, Chief Earnest insists that Adaeze find a way to work with her uncle in whatever capacity. It takes the threat of a hostile takeover by a rival company led by Chief Igwe Pascal (Kanayo O. Kanayo) and imminent bankruptcy for Lionheart Transport Company to look out for survival strategies. Adaeze will have to work with Godswill to rescue her beloved company in a male-dominated environment. Their collective efforts take them to northern Nigeria, where they negotiated a merger with a transport company with plans to expand east. The merger is mutually beneficial; they settle their loans and pushed back the hostile takeover amidst surprising twists and turns, misplaced trust and betrayals. Adaeze's competence and strength as a woman is tested against the force of patriarchy but she triumphs and the company is handed over to her to lead into the future. The film was directed by Genevieve Nnaji and who incidentally play the role of Adaeze.

\section{Methodological Premise}

Content analysis is the tool employed for the purpose of data collection and analysis in this study. According to Prasad (2008, p. 173), content analysis "is described as the scientific study of content of communication. It is the study of the content with reference to the meanings, contexts and intentions contained in messages." By virtue of this definition, content analysis is effective for analysing text, motion pictures and images. Thus, content analysis is adopted as the scientific method for data collection and analysis in this study.

\section{Content Analysis of Lionheart using Stereotype Content Model}

Stereotype content model (SCM) is a social psychology model developed by Amy Cuddy, Susan Fiske, Peter Glick and Jun Xu in 2001. It is used to explain the ambivalence that exists in societal stereotypes of targeted groups. Durante $(2008$, p.9) states that SCM "proposes potentially universal principles of societal stereotypes and their relation to social structure." The model postulates that people generally are viewed through a combination of two dimensions: warmth and competence. According to the model, perception of warmth and competence as well as the interactions are dependent on competition and status (Aromona, 2016). A group is considered 'warm' if they are subordinate and pose no threat and 'competent' if they are deemed 
to constitute a significant competition. These factors influence how a cultural out-group or sub-group is perceived. Fiske, Cuddy, Glick, and $\mathrm{Xu}$ (2002) argue that for every positive stereotype for warmth, there is a corresponding negative stereotype for low competence. On the other hand, a positive stereotype for competence acts jointly with a negative stereotype for low warmth.

This implies that for a subordinate or low-level group (e.g., elderly people), positive stereotype for warmth (affection, non-competitive) is accompanied by a negative stereotype for incompetence (dependent, incompetent). On the other side of the spectrum, a group that is positively stereotyped for competence (e.g., rich people) is resented for low warmth (cold, selfish). Fiske, Cuddy, Glick, and Xu (2002) argue that "the combinations of different stereotypic warmth and competence result in unique intergroup emotions - prejudice - directed toward various kinds of groups in society". As such, warm groups are pitied while the competent groups are envied.

\section{Table 1.Corresponding Forms of Prejudice as a Function of Perceived Warmth and Competence}

\begin{tabular}{|c|c|c|}
\hline & \multicolumn{2}{|c|}{ Competence } \\
\hline Warmth & Low & High \\
\hline High & $\begin{array}{l}\text { Paternalistic prejudice } \\
\text { Low status, not competitive } \\
\text { Pity, sympathy } \\
\text { (e.g., elderly people, disabled people, } \\
\text { housewives). }\end{array}$ & $\begin{array}{l}\text { Admiration } \\
\text { High status, not competitive } \\
\text { Pride, admiration } \\
\text { (e.g. in-group, close allies) }\end{array}$ \\
\hline Low & $\begin{array}{l}\text { Contemptuous prejudice } \\
\text { Low status, competitive } \\
\text { Contempt, disgust, anger, resentment } \\
\text { (e.g., welfare recipients, poor people) }\end{array}$ & $\begin{array}{l}\text { Envious prejudice } \\
\text { High status, competitive } \\
\text { Envy, jealousy } \\
\text { (e.g., Asians, Jews, rich people, } \\
\text { feminists) }\end{array}$ \\
\hline
\end{tabular}

This model has been widely applied to explain stereotypes across all levels and cultural groups in the society. It has found relevance also in media studies where it is employed to understand stereotypical portrayals of specific groups in society by the media. The manifest stereotype of women in films can be analyzed and appreciated through the stereotype content model (SCM). Women in films are generally stereotyped as 'warm' and the SCM maintains that they are perceived as warm only if they are in non-competitive roles such as housewives, objects of sexual gratification, nannies, cooks and house-girls, among other stereotypical portrayals. However, in cases where they enjoy a measure of liberty by having a strong career or being in position of 
authority, the stereotype quickly changes to that of resentment, envy or jealousy.

Stereotype content model, therefore, provides a compelling framework where a robust discussion and analysis of the stereotypical portrayal of marginalized groups such as women in films can be anchored. Nollywood as a film industry thrives on sustaining the stereotypical representation of women. Aromona (2016, p. 24) infers that Nollywood presents women as warm only when they are content being wives or mothers without the ambition of having a career outside the traditional role of housewife. Aromona (2016) further argues that gender stereotypes in Nollywood fall into quadrants with male stereotypes in high competence/low warmth quadrant and female stereotypes in low competence/high warmth. However, this changes for the female who is career driven (and competing for the same resources - work - as the male). Such female then falls into the high competence/low warmth quadrant as she is perceived to be cold ( $p$. 24).

\section{Unit of Data Analysis}

The study analyses the Nollywood film Lionheart. The analysis focuses on the visual rather than textual component of the film. Also, the unit of analysis will primarily be the lead and supporting characters. This is because they constitute a significant centre of the storyline through which the message and goal of the film is passed. For the purpose of this study, lead character means a figure whose role is central to the film, and who the film revolves around. A supporting character is operationalized to mean a character whose role is central to the overall plot but below that of the lead actor. As such, the lead and supporting characters identified will be evaluated based on predetermined demographics and character variables. Additionally, the stereotype content model will be employed to analyze factors such as setting, education, ambition, status and physical appearance to determine how Lionheart balances gender stereotypes.

Table 2. Subjects of Analysis

Subjects of Analysis

\begin{tabular}{lll}
\hline Lead Characters & Female & Male \\
Supporting Characters & Miss. Adaeze Obiagu & Mr. Godswill Obiagu \\
& Mrs. Abigail Obiagu & Chief Earnest Obiagu \\
& Miss. Onyinye & Mr. Samuel Akah \\
\hline
\end{tabular}




\section{Demographic Variables}

The age of the selected characters are divided into three (3) age groups: $25-39$ represents young adults, $40-64$ is coded as middleaged, and 65 and above is coded as older adults. Furthermore, the sexes of the characters are coded as male and female based on physical sex markers.

\section{Coding Categories}

Competence and warmth: according to the SCM, individuals and groups are stereotyped based on perceived competence and warmth (Fiske, Glick \& Xu, 2002). Consequently, characters that display traits like affection, care, gentleness, and empathy are categorized in the high warmth description and coded warm, whereas characters that display unaffectionate, selfish, and indifferent traits are rated in low warmth and coded as cold. Additionally, characters that are shown to be measured, intelligent, successful, and efficient will be rated high in competence, while characters that are represented to be unproductive, dependent, inefficient, and unintelligent will be scaled low in competence.

Setting: the environment that characters are shown in will be coded as traditional or professional setting. Traditional settings include homes, kitchen and market while professional setting includes workplace, offices and business engagements (Aromona, 2016).

Education: level of education is a prominent variable in gender stereotypes in Nollywood films. Therefore, characters that are suggested to be educated up to or above university level is coded high, while characters shown to be uneducated or educated below university level is coded low.

Ambition: professional drive and advancement are identifiable markers of an ambitious character. As such, characters will be assessed for traits that suggest their ambition, for which they will be coded high or low.

Gender representation: gender representation is a recurrent theme in the discourse about gender stereotype in films. Thus, portrayals that suggest sexual objectification, domestic use, courage, assertiveness, and in/dependence will be coded high or low.

Physical appearance: the attractiveness and physical appearance, including make-up and other props, will be assessed for suggestions of good looks, ugliness, neatness, composure, and body size. Physical appearance will be coded as high or low. 
Status: status, for the purpose of this study, will be operationalized to mean the marital status of characters. That will include the power they wield and the pressure mounted by social agents about their status. Therefore, the status of characters will be coded as married, unmarried (in a relationship or not in a relationship), and divorced (Aromona, 2016).

\section{Codebook}

\section{Table 3}

\begin{tabular}{|c|c|c|}
\hline & \multicolumn{2}{|c|}{ Level of Description } \\
\hline Stereotype Variable & HIGH & LOW \\
\hline Warmth & $\begin{array}{l}\text { Affectionate, gentle, } \\
\text { sympathetic, softhearted. } \\
\text { The character is } \\
\text { supportive, caring and } \\
\text { lovable. }\end{array}$ & $\begin{array}{l}\text { Unaffectionate, indifferent, } \\
\text { cold. The character is } \\
\text { unkind and incapable of } \\
\text { showing emotions. }\end{array}$ \\
\hline Competence & $\begin{array}{l}\text { Measured, intelligent, and } \\
\text { efficient. The character is } \\
\text { high-achieving, influential, } \\
\text { practical and shown to be } \\
\text { focused. }\end{array}$ & $\begin{array}{l}\text { Unintelligent, unproductive } \\
\text { and lacking expertise. The } \\
\text { character is shown to be } \\
\text { dependent, lacking } \\
\text { initiative. }\end{array}$ \\
\hline Setting & $\begin{array}{l}\text { Professional. Characters } \\
\text { are shown in offices and } \\
\text { other business places. }\end{array}$ & $\begin{array}{l}\text { Traditional. Characters are } \\
\text { shown at home, in the } \\
\text { market, kitchen and stores. }\end{array}$ \\
\hline Education & $\begin{array}{l}\text { Formal education up to or } \\
\text { above university level. } \\
\text { Character are shown to be } \\
\text { highly educated and } \\
\text { advanced. }\end{array}$ & $\begin{array}{l}\text { Informal or little education } \\
\text { below university and other } \\
\text { equivalent qualifications. } \\
\text { Characters are shown to } \\
\text { be illiterates, semi- } \\
\text { educated or drop-outs. }\end{array}$ \\
\hline Ambition & $\begin{array}{l}\text { Career focused. } \\
\text { Characters are depicted to } \\
\text { be professionally oriented } \\
\text { and focused on career } \\
\text { advancement outside the } \\
\text { home }\end{array}$ & $\begin{array}{l}\text { Not given to career. } \\
\text { Unambitious and restricted } \\
\text { to the house. }\end{array}$ \\
\hline Representation & $\begin{array}{l}\text { Sexual object, domestic } \\
\text { use, independent, foil. } \\
\text { Characters are shown to } \\
\text { be object of sexual } \\
\text { gratification, house help } \\
\text { and instrument of } \\
\text { destruction or frustration }\end{array}$ & $\begin{array}{l}\text { Not seen as object of } \\
\text { sexual gratification or } \\
\text { instrument of destruction } \\
\text { and are shown to be } \\
\text { significantly dependent on } \\
\text { others. }\end{array}$ \\
\hline Physical appearance & $\begin{array}{l}\text { Beautiful/handsome, well- } \\
\text { dressed. Characters are } \\
\text { shown to be beautiful and } \\
\text { dressed in manners that } \\
\text { are respectable. }\end{array}$ & $\begin{array}{l}\text { Ugly, shabbily dressed. } \\
\text { Characters are shown to } \\
\text { be unkempt, unattractive } \\
\text { and poorly or suggestively } \\
\text { dressed }\end{array}$ \\
\hline Status & $\begin{array}{l}\text { Married, unmarried but in a } \\
\text { relationship. }\end{array}$ & $\begin{array}{l}\text { Unmarried and not in a } \\
\text { relationship, divorced. }\end{array}$ \\
\hline
\end{tabular}




\section{Data Analysis}

Lionheart is a Nollywood film that follows the struggle of an ambitious woman as she strives to rescue their family transport company from imminent bankruptcy as well as manage the company going forward. The result obtained from the visual analysis of the film is contained in the tables below.

\section{Table 4. Analysis of Lead Characters}

\begin{tabular}{lllll}
\hline & \multicolumn{3}{c}{ Stereotype Descriptions } \\
\hline & $\begin{array}{l}\text { Lead } \\
\text { Character }\end{array}$ & Female & $\begin{array}{l}\text { Lead } \\
\text { Character }\end{array}$ & Male \\
\hline Stereotype Variables & High & Low & High & Low \\
\hline Warmth & $\sqrt{ }$ & $\sqrt{ }$ & $\sqrt{ }$ & $\sqrt{ }$ \\
Competence & $\sqrt{ }$ & $\sqrt{ }$ & $\sqrt{ }$ \\
$\begin{array}{l}\text { Setting } \\
\text { Education }\end{array}$ & $\sqrt{ }$ & & $\sqrt{ }$ & \\
$\begin{array}{l}\text { Ambition } \\
\text { Representation }\end{array}$ & $\sqrt{ }$ & & $\sqrt{ }$ & $\sqrt{ }$ \\
$\begin{array}{l}\text { Physical appearance } \\
\text { Status }\end{array}$ & $\sqrt{ }$ & & $\sqrt{ }$ & \\
\hline
\end{tabular}

The lead female character Adaeze Obiagu (Genevieve Nnaji), is stereotyped in manners that are traditionally associated with men in Nollywood movies. She is revealed to be professionally inclined, competent, intelligent, and highly-educated; traits that are mostly the preserve of men in Nollywood films. Also, Adaeze is shown to be unmarried and an object of sexual exploitation. The male lead character is revealed to be quite emotional and incompetent. His level of education is questionable as well (refer to table 3 above).

\section{Table 5. Analysis of Supporting Characters}

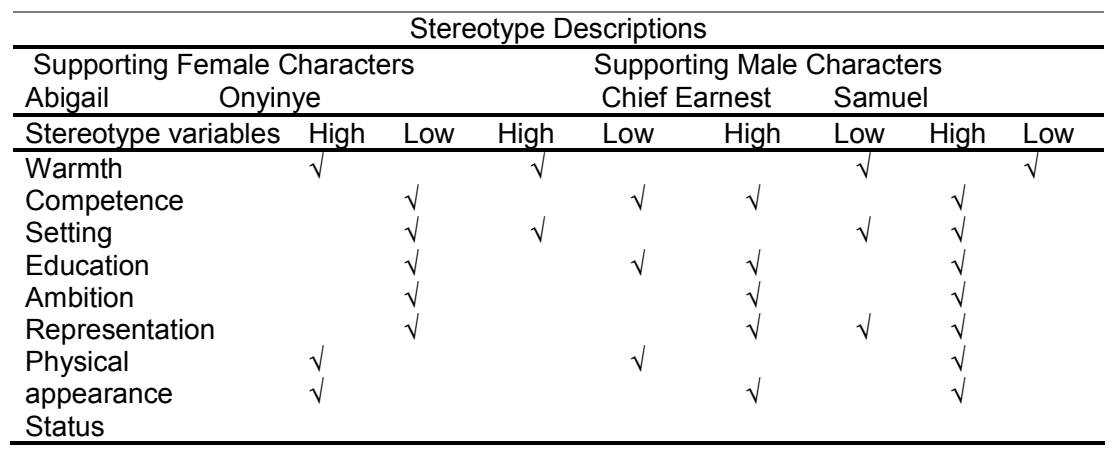


The supporting female characters, as the result shows, were depicted in the traditional roles typically assigned to them in Nollywood films. Abigail is a stay-at-home mother with little interest in business, while Onyinye remains a Personal Assistant to the lead female character. On the other hand, the supporting male characters are formidable in their general perception as astute, practical and knowledgeable individuals. The only exception will be Samuel Akah who was represented as an agent of destruction, albeit in a business environment (refer to table 3 ).

\section{Discussion of Findings}

The study sought to investigate how Nollywood is balancing gender stereotypes in films, using Lionheart; a film directed by Genevieve Nnaji. Thus, analysis of the result and discussion of findings will hinge on the research questions.

\section{Balancing gender stereotype in Lionheart against the wider social stereotype of gender}

From the data analysis, little has changed in Nollywood's stereotypical portrayal of both genders. While there is an exception to the role and character of the lead actress, the portrayal of other females in the film follows the traditional narrative. The lead actress, Adaeze, is portrayed as a quintessential modern woman: powerful, intelligent, highlyeducated, ambitious, and emotionally in control. She was introduced from the beginning as a confident woman who could face off a dangerous crowd of touts and thugs without losing her mind. Subsequent screen time will see her take the driving seat of her father's transport company against the envy and resentment of a male director of engineering services. This is line with the assumption of the stereotype content model that a competent woman will typically be envied and resented in the society (Fiske, Glick, \& Xu, 2002). Furthermore, some recurring elements of female stereotypes persisted in the film. For instance, Adaeze was shown to be unmarried and not in a relationship. This plays into the widespread perception that a career-oriented woman cannot have or manage a romantic relationship. Additionally, Adaeze was represented as an object of male sexual exploitation evidenced in the way a bank manager desired her as his 'price', and how another man was staring at her chest area. It took the intervention of Godswill to stop the suggestive gaze of the man. This also confirms the perception that women are dependent on and meant to be protected by men (Wood, 1994).

In addition, Onyinye was the personal assistant to Adaeze, which plays to the traditional perception of women in society as good for low 
to middle-level professional careers. More so, Mrs. Abigail Obiagu, mother of Adaeze, is depicted in the traditional interpretation of women's roles in society. She was a diligent and caring mother who showed no interest in business or the kind of ambition Adaeze has. This corroborates the findings of Aromona (2016, p. 43) that "a woman's worth, as seen in the coded Nollywood movies, is based on her ability to be a perfect homemaker with roles including but not limited to meeting the husband's sexual desires, cooking for the man, and tending the children." For the male part, it appears to be business as usual. The male characters in the film largely retained their traditional roles. The slight exception would be Godswill whose role was comedic and incompetent, but effective in helping Adaeze achieve her goal. Chief Earnest and Samuel were proper competent males who generally flowed with their cinematic and socially constructed stereotype. The males in their roles were dominant, capable, and confident. Another male who appeared incompetent was Obiora, Adaeze's younger brother, whose role was minor. However, even that was sorted out in the end as he became successful in the pursuit of his musical career. Although, Lionheart succeeded in elevating the woman and reflecting her ambition, power and capability; all of these, however, occurred without upsetting male dominance and privileges. Men were effectively in control and it took a male to help Adaeze overcome a major crisis in her family business. This further reinforces, if not intentional, the social perception that women are dependent on men, and are generally warm.

\section{Conclusion}

Genevieve Nnaji directed Lionheart. Her influence is visible as she attempts to explore another angle about female stereotype in films. The interpretation of the character, Adaeze was spot on and reflects a growing desire to retell the story of the woman through motion pictures. It is recommended, then, that more women should be involved in filmmaking. This will influence the perception of women in no small measure, as well as educate the society, and steer the discourse away from female weaknesses to their strengths. Furthermore, there should be an active effort by filmmakers to 'demystify' the power of men. The cinematic representation of men is typically as competent. Future films should attempt to explore male weaknesses and incompetence to further balance the existing stereotype around men. Lionheart is by and large a balanced film. It provides a solid background on which productive dialogue about gender stereotypes in Nollywood can be anchored and questions addressed. The issues raised are topical and patently relevant to feminist discourse on women's representation in films, and in the media generally. More so, it provides a way forward 
for gender-based discourse and serves as a point of reference for other female directors willing to interpret the role of women in a manner that is more accurate and truthfully reflective of their strengths and capacities. Recent global events have made this call even more critical. Whatever will happen in the coming decade will be driven by the media, and the film industry will be at the forefront of these events.

\section{References}

Adewoye, O. A., Odesanya, A. L., Abubakar, A. A., \& Olatunji, J. (2014). Rise of the 'homo erotica'? Portrayal of women and gender role stereotyping in movies: analysis of two Nigerian movies. IISTE: Developing Country Studies, 4(4), 103-110.

Aromona, O. (2016). Portrayal of African women in Nollywood films over a 5-year period: A content analysis of traits applying the stereotype content model. Johnson City: East Tennessee State University.

Chowdhury, M., Landesz, T., Santini, M., Tejada, L., \& Visconti, G. (2008). Nollywood: The Nigerian film industry. Boston: Harvard Business School.

Cloete, A. L. (2017). Film as medium for meaning making: A practical theological reflection. HTS Teologiese Studies/Theological Studies, 73(4), 1-6.

Council of Europe. (2018). Gender equality. Retrieved 22 January 2019, from https://www.coe.int/en/web/genderequality/ gender-stereotypes-and-sexism.

Cuddy, A. J., Fiske, S. T., Kwan, V. S., Glick, P., Demoulin, S., Leyens, J.-P., \& Petkova, K. (2009). Stereotype content model across cultures: Towards universal similarities and some differences. British Journal of Social Psychology, 48, 1-33.

Dutt, R. (2014). Behind the curtain: Women's representations in contemporary Hollywood. London: Media@LSE, London School of Economics.

Ellemers, N. (2018). Gender stereotypes. Annual Review of Psychology, 69, 275-298.

Enna, D. M., Idakwo, E. P., \& Akpovye, O. D. (2015). The impact of the 'magic' in Nollywood: An analysis. American International Journal of Contemporary Research, 5(5), 177-187.

Fiske, S. T., Cuddy, A. J., Glick, P., \& Xu, J. (2002). A model of (often mixed) stereotype content: Competence and warmth respectively follow from perceived status and competition. Journal of Personality and Social Psychology, 82(6), 878902. 
Fosudo, S. (2012). Nollywood: The reality and illusions of a film industry in transition. In S. Femi, \& O. O. Mosunmola (Eds.). Music and theatre arts in Africa (pp. 95-105). Lagos: Centre for Information, Press and Public Relations, Lagos State University.

Ibbi, A. A. (2017). Stereotype representation of women in Nigerian films. Cinema Journal, 6(2), 50-70.

Kumari, A., \& Joshi, H. (2015). Gender stereotyped portrayal of women in the media: perception and impact on adolescent. IOSR Journal of Humanities and Social Science (IOSR-JHSS), 20(4), 44-52.

National Bureau of Statistics. (2016). Statistical report on women and men in Nigeria. Abuja: National Bureau of Statistics.

Oak Foundation. (2015). Investigation of the impact of gender representations in Nigeria films. New York: Geena Davies Institute on Gender in Media.

Office of the High Commissioner for Human Rights. (2014). Gender stereotypes and stereotyping and women's right. Geneva: Women's Right and Gender Section.

Okafor, N. (2017). The felonious stereotyping of the woman in Nollywood films. Unizik Journal or Arts and Humanities, 17(3), 276-299.

Okunna, C. S. (2005). Gender and communication in Nigeria: Is this the 21st century? Retrieved 5 February 2019, from http:// www.portalcomunicacion.com/bcn2002/n_eng/programme/ prog_ind/papers/o/pdf/o005se04_okunn.pdf.

Omoera, O.S. (2017). Nollywood unbound: Benin language video-films as paradigm. In James T. Tsaaior and Francoise Ugochukwu (Eds.). Nigerian Film Culture and the Idea of the Nation: Nollywood and National Narration (pp.175-205). London: Adonis and Abbey.

Onuzulike, U. (2009). The birth of Nollywood: The Nigerian movie industry. Black Camera, 22(1), 25-26.

Opeyemi, F. K. (2008). Nollywood portrayal of the Nigerian society: Issues in question. International Journal of Communication, 9 , 282-290.

Prasad, D. B. (2008). Content analysis: A method in social science research. In L. K. Din \& B. Vanila (Eds.). Research method for social work (pp. 174-193). New Delhi: Rawat Publications.

Wood, J. T. (1994). Gendered media: The influence of media on views of gender. In J. T. Wood, Gender lives: Communication, gender, and culture (pp. 231-244). Belmont, California: Wadsworth Publisher. 